\title{
光ファイバセンサ
}

\author{
保立和夫 \\ 東京大学大学院工学系研究科 電気系工学専攻 ( ₹ 113-8656 東京都文京区本郷7-3-1)
}

\section{Optical Fiber Sensors}

\author{
Kazuo HOTATE \\ Department of Electrical Engineering and Information Systems, School of Engineering, The University of Tokyo, \\ 7-3-1 Hongo, Bunkyo-ku, Tokyo 113-8656
}

(Received February 11, 2013)

\begin{abstract}
Optical fiber sensors have been developed since 1970's, and several systems have already been used in practical applications. History of this technological field is reviewed, at first, through looking at the activities shown in the International Conference on Optical Fiber Sensors (OFS). The latest OFS, which was held last year in Beijing, is also reviewed briefly for checking the recent tendency in this field. Then, fiber optic nerve systems are discussed, as a recent topic among the various types of optical fiber sensors.
\end{abstract}

Key Words: Optical fiber sensors, Fiber optic nerve systems, Smart materials and smart structures

1. はじめに

光ファイバの損失が $20 \mathrm{~dB} / \mathrm{km}$ を切り，半導体レーザが 室温連続発振を成し遂げたという「光ファイバ通信」に とって画期的な出来事は，いずれも1970年のことであっ た.この年を光ファイバ実用化システムの研究・開発元 年とすれば,「光ファイバセンシング」の歴史もこの年か ら始まる。本稿では, 情報化社会の中核技術として利用 されている「光ファイバ通信」の双子の兄弟として成長し てきた「光ファイバセンシング」について述べる。

40年にも亘る長い研究・開発の歴史の中で, 光ファイ バジャイロ, 光ファイバ電流センサ, 光ファイバ分布型 温度センサ等, 既に実用域に達した複数の技術が社会に 送り出されている。 そして, 最近の大きなトピックのひ とつは,「痛みの分かる材料・構造の為の光ファイバ神 経網技術」である.

\section{2. 光ファイバセンサの方式分類}

光ファイバセンサ ${ }^{1,2)}$ を光システム構成から分類する と, Fig. 1のようになる.

Fig. 1 (a) は, 光ファイバを情報伝送路とした最も簡 単な構成であるが, それでも, 遠隔計測, 強電磁場計 測, 高電圧下計測等, 従来の電気式センサでは得難い特 徵を実現する. Fig. 1（b）の構成では, 光ファイバがセ ンサとして活用され, 温度, 歪, 磁界等によってその長
さや屈折率を変化させる様子を干渉によって高精度に測 定する干渉測定型構成, 電流や磁界により光ファイバが 示すファラデー効果を活用した偏波測定型構成, 被測定 量による光伝送損失の変化を捉える損失測定型構成な ど，種々の方式が研究・開発されてきた。

Fig. 1 (c) の構成は, 光ファイバに沿う分布量や光 ファイバに沿って多数配置されたセンサからの情報を取 得する構成である．光ファイバに沿う温度や歪を分布的 に捉える「分布型構成」と, 光ファイバに沿って複数配置 したセンサ情報を取得する「多点型構成」とに大別され る.

環境にやさしい社会, 持続可能な社会の実現が求めら れる現在, 社会は使い捨てからメンテナンス重視へと舵 を切った．橋梁やビルといった社会インフラや航空機の 翼等の健全性診断を行って, 適当な改修を施しつつ大切 に活用し続けて行くことが求められている。分布型・多 点型光ファイバセンシングは,「痛みのわかる材料・構 造の為の光ファイバ神経網」として重要となってきた.

\section{3. 光ファイバセンサ技術の歴史と現在}

\section{1 光ファイバセンサ国際会議}

光ファイバセンサ分野の国際会議として，1983年以来 継続開催されている「光ファイバセンサ国際会議 (International Conference on Optical Fiber Sensors: OFS)」を振り 返り ${ }^{3-5)}$ ，本分野の歴史と現在を概観する. 


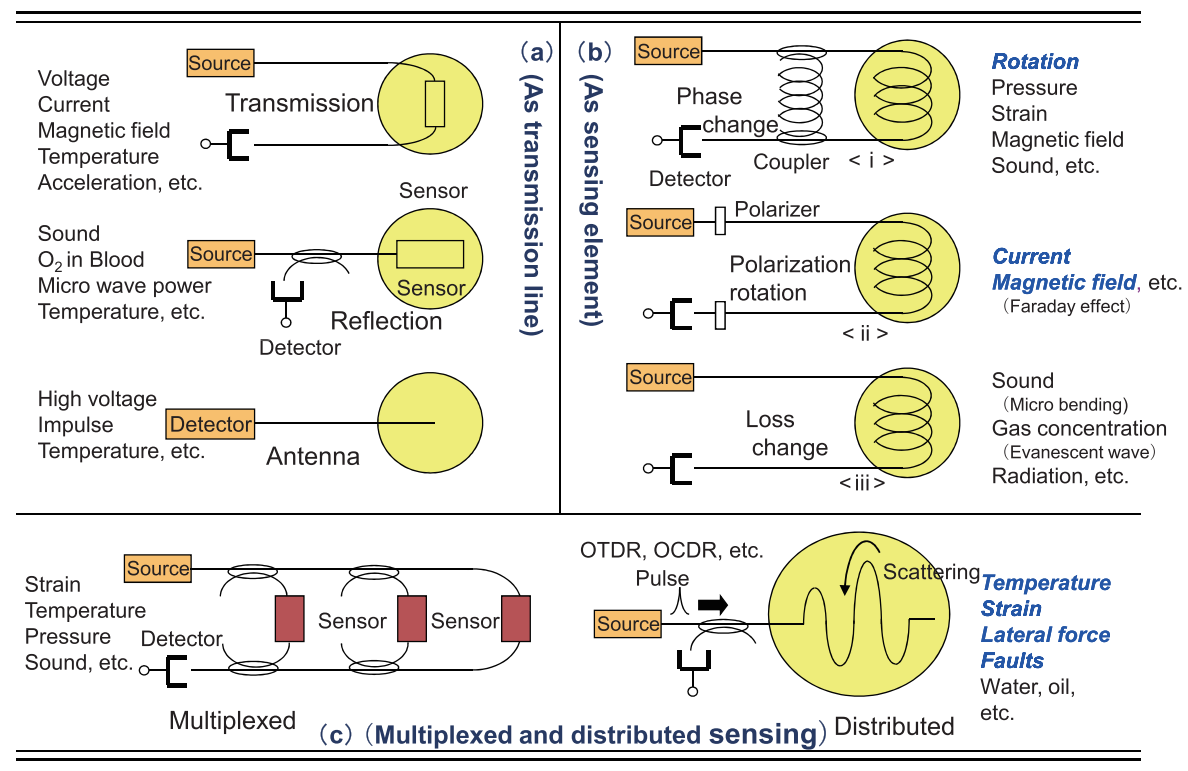

Fig. 1 Classification of Optical Fiber Sensors. (a) Systems with optical fiber as signal transmission line, (b) systems with optical fiber as sensing head, and (c) systems for multiplexed and distributed sensing.

本会議は, ロンドンで第1回が開催されて以来, Table 1に示したように, ヨーロッパ, アメリカ, アジ ア・オセアニアを 1.5 年ごとに巡回開催されてきた。筆 者は，その第2回会議から直近の第22回に至るまでの28 年間，本国際会議に連続して出席している。我が国でも 第4回，第11回，第16回が開催され，また第13回の韓国 開催ではプログラム委員会の運営を我が国が担当した。

第1回会議では50件であった発表件数も, 徐々に増加 した，最近ではさらに急増し，昨年の北京会議では400 件近くにもなっている，我が国からの発表件数は，ほぼ 毎回, 開催国に次ぐ件数あるいは最多の発表であった が，ここ数回は中国の躍進が目立つ。それでも，第21回

Table 1 History of the International Conference on Optical Fiber Sensors (OFS).

\begin{tabular}{lllr}
\hline & \multicolumn{1}{c}{ Y/M/D } & \multicolumn{1}{c}{ City } & Paper No \\
\hline OFS-1 & $1983 / 4 / 26-28$ & London, UK & 50 \\
\hline OFS-2 & $1984 / 9 / 5-7$ & Stuttgart, Germany & 85 \\
\hline OFS-3 & $1985 / 2 /$ & San Diego, USA & 85 \\
\hline OFS-4 & $1986 / 10 / 7-9$ & Tokyo, Japan & 103 \\
\hline OFS-5 & $1988 / 1 / 27-29$ & New Orleans, USA & 84 \\
\hline OFS-6 & $1989 / 9 / 18-20$ & Paris, France & 103 \\
\hline OFS-7 & $1990 / 12 / 2-6$ & Sydney, Australia & 106 \\
\hline OFS-8 & $1992 / 1 / 29-31$ & Monterey, USA & 108 \\
\hline OFS-9 & $1993 / 5 / 4-6$ & Firenze, Italia & 140 \\
\hline OFS-10 & $1994 / 10 / 11-13$ & Glasgow, Scotland & 167 \\
\hline OFS-11 & $1996 / 5 / 21-24$ & Sapporo, Japan & 158 \\
\hline OFS-12 & $1997 / 10 / 28-31$ & Williamsburg, USA & 149 \\
\hline OFS-13 & $1999 / 4 / 12-16$ & Kyongju, Korea & 218 \\
\hline OFS-14 & $2000 / 10 / 11-13$ & Venice, Italy & 152 \\
\hline OFS-15 & $2002 / 5 / 6-10$ & Portland, USA & 199 \\
\hline OFS-16 & $2003 / 10 / 13-17$ & Nara, Japan & 271 \\
\hline OFS-17 & $2005 / 5 / 23-27$ & Bruges, Belgium & 293 \\
\hline OFS-18 & $2006 / 10 / 23-27$ & Cancun, Mexico & 246 \\
\hline OFS-19 & $2008 / 4 / 14-18$ & Perth, Australia & 292 \\
\hline OFS-20 & $2009 / 10 / 5-9$ & Edinburgh, UK & 363 \\
\hline OFS-21 & $20011 / 5 / 15-19$ & Ottawa, Canada & 382 \\
\hline OFS-22 & $20012 / 10 / 15-19$ & Beijing, China & \\
\hline & & & \\
\hline
\end{tabular}

での我が国の発表件数は38件，また，第22回北京会議で も29件で，いずれも中国につづいて2番目に多い件数で ある。しかし，北京会議での中国の発表件数は144件と 群を抜いており，本分野での同国の活力を感じさせる. 一方で，注目分野での発表が主に含まれるオーラルセッ ションでの発表件数を見ると，1位の中国が13件に対し て，我が国は8件と2位につけ，その差は縮小してくる。

\subsection{OFS北京会議でのセッション構成}

Table 2に, 北京会議でのオーラルセッションとワーク ショップのタイトルをまとめた ${ }^{5)}$. オーラルセッション での発表件数は，招待講演を含めても，全382件中の 81 件と少ないが，現在の注目研究領域を示す指標としての 意味を持つ。

Distributed Sensing領域において歪や温度を分布測定す るための計測原理である光ファイバ中のブリルアン散乱 に関する研究論文は81件中で18件と最多であり，次に多 点型センシングのためのセンサヘッドとなる光ファイバ グレーティング関連の発表が17件とつづく。「痛みの分 かる材料・構造の為の光ファイバ神経網」が注目研究領 域であることが分かる.

初期のOFS会議では, 物理量, 機械量, 電気量, 化学 量センサ, Interferometry, Polarimetoryセンシング，関 連デバイスといったカテゴリーが使われてきた。また， 初期から中期にかけては, 光ファイバジャイロ, 光ファ イバ電流センサ，光ファイバハイドロホンといった具体 的なセンサがカテゴリーとして掲げられていた。 これら はTable 2にはもはやないが，既に技術が進展して実用期 に入ったことを意味している。

通信線路としての光ファイバを監視する技術として, 1976年に考案されたOptical Time Domain Reflectometry (OTDR) 技術は，光ファイバセンシング分野でも技術提 案の新たな種となった。英国サザンプトン大のHartog博 
士は，1983年に液体コア光ファイバの散乱強度が温度依 存性を持つことを活用し，OTDR技術によって，分布型 温度センシングを初めて提案・実証した6)。その 1 年後, 同大学のDakin教授により, ラマン散乱のストークス光 とアンチストークス光の強度比が温度情報を与えること を活用して，OTDRによる分布型温度センシングが提 案・実証された7)。現在，本技術は実用化が大きく進展 している.

一方, NTTの堀口博士らは, 1989年に, ブリルアン散 乱の周波数シフトから温度あるいは伸縮歪が測定できる ことを示し，やはりOTDR技術によって分布型歪(温度) センシングを提案・実証し ${ }^{8}$, Brillouin Optical Time Domain Analysis (BOTDA) と名付けた.

分布センシング原理としては，連続光を用いる技術も 提案されてきた，たとえば筆者らは，1998年に連続光波 の相関特性を合成することによって，光ファイバに沿う ブリルアン散乱スペクトルの分布を高い空間分解能と速 い高測定速度で測定できる「ブリルアン光相関領域解析 法」(Brillouin Optical Correlation Domain Analysis: BOCDA）を提案した ${ }^{9)}$.

これらの分布型・多点型光ファイバセンシングは, OFS会議でも，その中期以降に大きな話題となってい る. Table 2中のDistributed Sensing, Sensor Network and Multiplexing, Fiber Grating Sensorsが本技術に対応する。

フォトニック結晶光ファイバ $(\mathrm{PCF})$ などの特殊光ファ イバの提案・研究の展開に合わせ, これらを活用したセ ンサ技術の研究も活発である. PCF光ファイバの一種の Photonic band-gap fiber(PBF)では，光が伝搬するコア部 分が空隙である。ここに被測定物質を挿入し, 光との相 互作用長を延ばすことで感度向上などを図った多様なセ ンシング技術が提案されている. Table 2では, Microand Nano-Structured Fiber Sensorsが対応する.

OFS北京会議では“Special Workshop on Industrial Progress, Commercial Systems and Field Tests”というシンポジ ウムが企画された ${ }^{5}$. これまでの研究成果が社会で活用 されている様子を窥うことができる，取りあげられた技

Table 2 Titles of the oral sessions and the workshops in OFS-22 held in Beijing in 2012.

Oral Session Titles in OFS-22

+ Physical and Mechanical Sensors

+ Biomedical and Chemical Sensors

+ Fiber Grating Sensors

+ Sensor Network and Multiplexing

+ Distributed Sensing

+ Micro- and Nano-Structured Fiber Sensors

+ Slow and Fast Light, and Other Emerging Technologies

+ Sensor Application and Field Tests

Workshop Titles in OFS-22

+ Special Workshop on Industrial

Progress, Commercial Systems and Field Tests

+ Fiber Optic Gyro - 35 Anniversary Workshop -
術には，光コヒーレンストモグラフィ, FBGの歪センサ 応用，BOTDAによる構造ヘルスモニタリング， BOTDA の石油・天然ガス分野への利用，ラマン散乱を活用した 分布型温度センシング技術(ROTDR), 分布型化学量セ ンシング，光ファイバ中のファラデー効果の活用による 電力分野用電流センサ，そして，ハイドロホンなどがあ る. ROTDRによる分布型温度センサは，油井をはじめ 様々な用途で数多く導入・活用されている.

\section{3 光ファイバジャイロ技術}

2011年は, 光ファイバジャイロ (Fiber Optic Gyro: FOG) 提案から35周年であった。OFS北京会議では，こ れを記念して, “Fiber Optic Gyro - 35 Anniversary Workshop”も開催された ${ }^{5)}$. 米国, ヨーロッパ, 日本, 中国等 におけるFOGの実用化の様子や，新しい研究・開発の動 きが発表された。今回, 複数の発表に登場したキーワー ドは, FOGの宇宙応用であり，人工衛星やその他の宇宙 機へのFOGの応用が世界的に展開されている。また, 1 世紀に1回転という超高感度FOGの開発が，欧米ならび に我が国で進んでいる。この他，PBFファイバによる FOG中の各種雑音要因の低減研究や, 光ファイバリング 共振器による共振方式FOGの研究も発表された.

光ファイバジャイロは，サニャック効果に基づくジャ イロであり, 可動部分が皆無, 瞬間起動, メンテナンス フリー, 広ダイナミックレンジ等の特徴を有する ${ }^{10,11)}$.

干涉方式光ファイバジャイロ(Interferometer FOG: I-FOG)では，長尺光ファイバを小半径のコイルにする ことで，小型化と高感度化を両立させた。 といっても， 航空機の慣性航法用ジャイロには， $0.01 \% \mathrm{~h}$ (地球の公転 速度相当)という分解能が要求される. 直径 $10 \mathrm{~cm}$, 長さ $1 \mathrm{~km}$ のコイルでも, 本要求性能は両光間位相差にして $1 \mu \mathrm{rad}$ にかならない. 光ファイバ中で生じる偏波変 動, 後方散乱, 光カー効果, 地磁気によるファラデー効 果, 不均一な温度分布の時間変動等により, 雑音が生じ る。これまでに, 多くの研究が蓄積されて, 光源として 低コヒーレンス光源を使うなどの有効な対策が考案さ $れ^{10-12)}$ ，I-FOGは実用化が進んでいる.

ボーイング777の開発にあたってI-FOGが採用され た. 宇宙科学研究所 (現, JAXA宇宙研)では, M-Vロ ケットにI-FOGを用いた慣性航法装置を搭載してきた。

M-V第1号機(1997年) で打ち上げられた人工衛星 Muses-B(はるか)や，2005年夏にJAXA宇宙研が打ち上 げた小型人工衛星「れいめい」でもI-FOGが使われた ${ }^{13)}$. 2010年に打ち上げられたソーラー電力セイル実証衛星 「IKAROS」等も，I-FOGで航行している ${ }^{14)}$.

民生応用も開拓していて，カーナビ，自動走行車の姿 勢制御・ナビゲーション，アンテナ/カメラの安定台， ラジコンヘリコプター制御, クレーン制御, 農業機器の 制御，ヒューマノイドロボットの姿勢制御等に活用され てきた ${ }^{10)}$ 。ヘリコプターから望遠カメラで地上を捉えた ブレのない画像もI-FOGカメラ安定台が提供している.

宇宙望遠鏡等の制御や宇宙を長期間旅するミッション には， $0.0001 \%$ h $(1$ 世紀に1回転 $)$ という超高感度なI-FOG 
も必要となり,その開発も進んでいる ${ }^{15-17)}$ 。また, $\mathrm{PBF}^{18)}$ では原理的に, 散乱, 非線形性, ファラデー効 果，温度係数等が小さくなる ${ }^{19)}$ ，そこで，PBFを干渉型 光ファイバジャイロのセンシングコイルに利用して, 上 記物理現象から発生していた雑音を低減する提案・研究 もなされている ${ }^{19-21)}$.

光ファイバに沿う温度分布が時間的に変化すると, 大 きなジャイロドリフトが生じる ${ }^{22)}$. ファイバ長を短くす ることが有効な解決策である。 そこで，光ファイバリン グ共振器の鋭い共振特性を活用し, 光ファイバ長を I-FOGに比べ圧倒的に短くできる「共振方式光ファイバ ジャイロ」(Resonator FOG: R-FOG)が注目される ${ }^{23,24)}$.

筆者らは, R-FOGの雑音要因の挙動把握とその対策に 関する研究を蓄積してきた ${ }^{10)}$ 。これらの成果を活用し て, 最近, 新たなR-FOG実験系を構築した ${ }^{25,26)}$. 共振器 は偏波維持光ファイバで構成し, 偏波軸を2箇所で90度 捻って融着する新しい技術を提案・導入した，本質的に 2つ存在する共振偏波状態(固有偏波状態：ESOP)のうち から一つだけを選択的に励振することを可能にし, 偏波 変動誘起ドリフトの低減を実証した25)。ここでは, ジャ イロ信号の処理と雑音除去を統合して行えるバイポーラ デジタルセロダイン方式を提案・導入している232,25,26).

\section{4. 痛みの分かる材料構造のための光ファイバ神経網}

\section{1 分布型・多点型光ファイバセンサの構成分類}

社会は, 使い捨てからメンテナンス重視へと舵を切 り，様々な社会的インフラのライフサイクルを延伸する ことが重要となっている。この要求を実現する上で「痛 みの分かる材料・構造のための光ファイバ神経網」が必 要である. Fig. 2に, 本技術の分類を示す.

Fig. 2 (a) の分布型構成では, 光ファイバ中で生じる レーリー散乱, ラマン散乱, ブリルアン散乱等を活用す る。これら散乱の強さあるいは周波数は, 温度や歪によ り変化する。一方で, 散乱が生じた場所を特定する技術 も種々提案されている 沿って多くのセンサを多点配置した多点型構成であ $ろ^{2)}$. Fig. 2(c) は, 比較的短い分布型センサヘッドを多 点化した構成である。これら「光ファイバ神経網技術」に 関し，本稿ではブリルアン散乱の活用技術を中心に最近 の技術的展開を述べる.

光ファイバの材料分子 $\left(\mathrm{SiO}_{2}\right)$ の熱振動は微弱な超音波 を作る，超音波の波長が入射光波長の半分になると，音 波による位相回折格子はブラッグ条件を満たし, 光は反 射される。これがブリルアン散乱である。ブリルアン散 乱光はドップラーシフトを受けて周波数が低下する。 こ の周波数シフト量 (ブリルアン周波数シフト：BFS, 約 $11 \mathrm{GHz})$ は, 温度 $\left(1 \mathrm{MHz} /{ }^{\circ} \mathrm{C}\right)$ ならびに歪 $(500 \mathrm{MHz} / \%) に$ 対して線形に変化する 2 .

光ファイバに片端から光を入射すると, 自然ブリルア ン散乱が返ってくる。これを活用する方法をReflectome$\operatorname{try}($ リレクトメトリ：R）と呼ぶ。この方式では, 自然 散乱と参照光を干渉させて両者のビートとしてブリルア

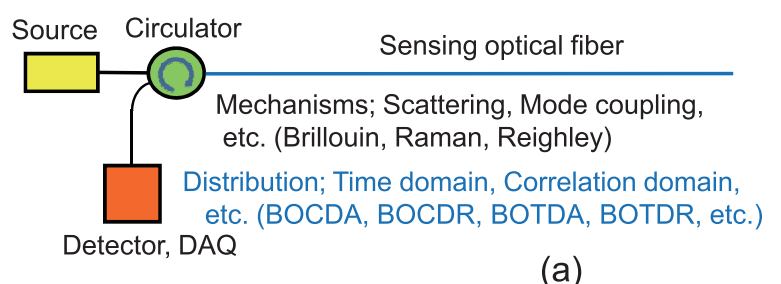

(a)
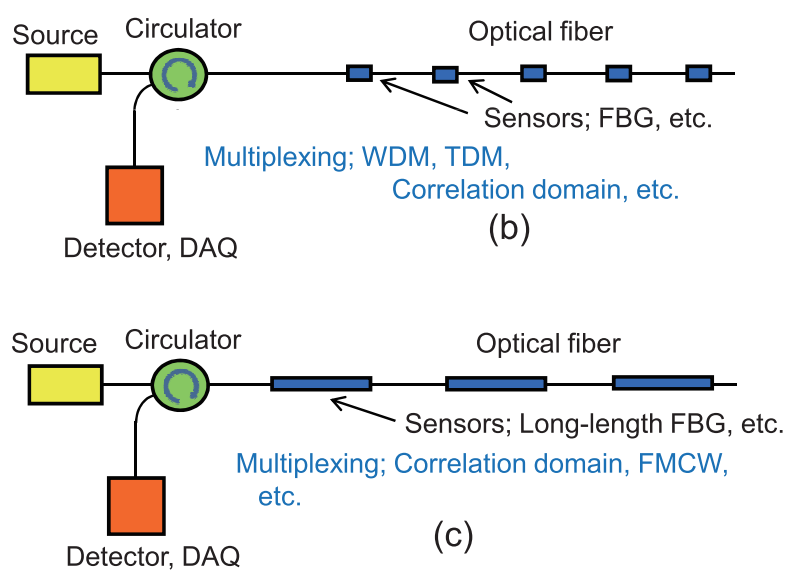

Fig. 2 Classification of fiber optic nerve systems. (a) Distributed sensing scheme, (b) multiplexed sensing scheme, and (c) quasi-distributed sensing scheme.

ン利得スペクトル $(\mathrm{BGS})$ を測定し，そのピーク周波数と してBFSを得る. 光ファイバの他端からBFS相当だけ周 波数を低減させた光を入射すると, 両光(ポンプ光とプ ローブ光)の差周波数成分によって超音波が強められ, 誘導ブリルアン散乱が生じる。これを活用する方法を Analysis(解析法：A）と呼ぶ。この周波数差を掃引させ つつ散乱強度を測定することで，BGSを測定してBFSを 得る. 前者は光ファイバの片端のみから光を入射するこ とでセンシングができる利点を有し，後者は相対的に強 い誘導散乱を利用できるのでSN比に優れ，速い測定が 可能となる.

位置情報を取得する技術としては，光パルスを入射し 後方散乱を時間分解測定して位置情報を得るTime Do-

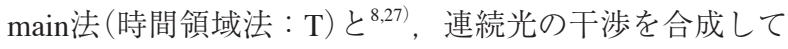
位置情報を得るCorrelation Domain法 (相関領域法 : C) と がある9．つまり，ブリルアン散乱を利用した分布測定 法には, BOTDR法, BOTDA法, BOCDR法, BOCDA法 が提案されている。

時間領域法の基本システムでは空間分解能は本質的に 約1 mに制限される2). BGSは30 MHzのスペクトル幅を 持つ. 一方, 空間分解能 $1 \mathrm{~m}$ に対応した幅 $1 \mathrm{~m} の$ 光パル スは約100 MHzのスペクトル幅を持つので, 歪感度と空 間分解能にはトレードオフが存在するからである。この 問題を解決する手法が提案されているが27)，得られる久 ペクトルの形状が複雑であったり，また本質的に超高速 なデータ取得エレクトロニクスが要求される $(1 \mathrm{~cm}$ 分解

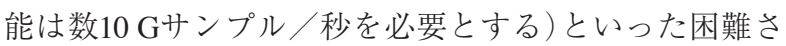
を伴う ${ }^{27-31)}$. 
相関領域法には時間分解法で生じた空間分解能制限要 因は働かない，連続光であるのでエネルギー利用効率も 良く, 高速測定にも適している，光ファイバに沿う任意 の複数点にランダムアクセスできるという特徴もある.

\section{2 ブリルアン光相関領域法}

Fig. 3 (a) は, BOCDA法のシステム構成例である ${ }^{32}$. 被測定光ファイバにBFS程度の光周波数差を有するポン プ光とプローブ光を対向伝搬させて誘導ブリルアン散乱 を発生させる。ここで，レーザ光源の発振周波数を正弦 波で変調するのが本技術のポイントである。これによ り, Fig. 3 (b)のように, 誘導ブリルアン散乱を位置選 択的に発生させる. 局在発生位置は変調周波数の変化で 掃引でき，分布センシングが実現される。

BOCDA法により, 空間分解能7 $\mathrm{cm}$ で1 kmを超える分 布測定 ${ }^{33)}$, 空間分解能 $1.6 \mathrm{~mm}$ (世界最高 $)^{34)}$, 単点におけ る $1 \mathrm{kHz}$ の測定速度 ${ }^{35}$ 等が実現されている。 また，同技 術により,「痛みの分かる材料・構造」の実証研究とし て. 小径パイプ(直径 $15 \mathrm{~cm}$, 周囲約 $50 \mathrm{~cm}$ ) 周囲の歪分布 測定 $(1 \mathrm{~cm} \text { 空間分解能 })^{36)}$ ，鉄筋コンクリートクラックの 検出 $(0.1 \mathrm{~mm} \text { クラック })^{37)}$, 高層ビルモデルの地震振動下 での多点・動的歪センシング（振動下で塑性変形限界を 超える状況把握 ${ }^{38)}$, 航空機機体の歪分布計測と多点. 動的歪計測 (実機の飛行状態でのヘルスモニタリング機 能実証 $)^{39)}$ ，航空機用カーボンファイバ強化樹脂のボル 卜接続部分での劣化モニタリング $(\mathrm{CFRP}$ に埋め込んだ光 ファイバ神経網でボルト周りの劣化診断 ${ }^{40)}$ 等が行われ ている。

Fig. 4は, BOCDAによる1.6 mmの空間分解能の実証実 験である. $3 \mathrm{~mm}$ の空隙を空けて移動台に接着した光 ファイバを引っ張り, $3 \mathrm{~mm}$ 部分の歪の増加と, 接着剤
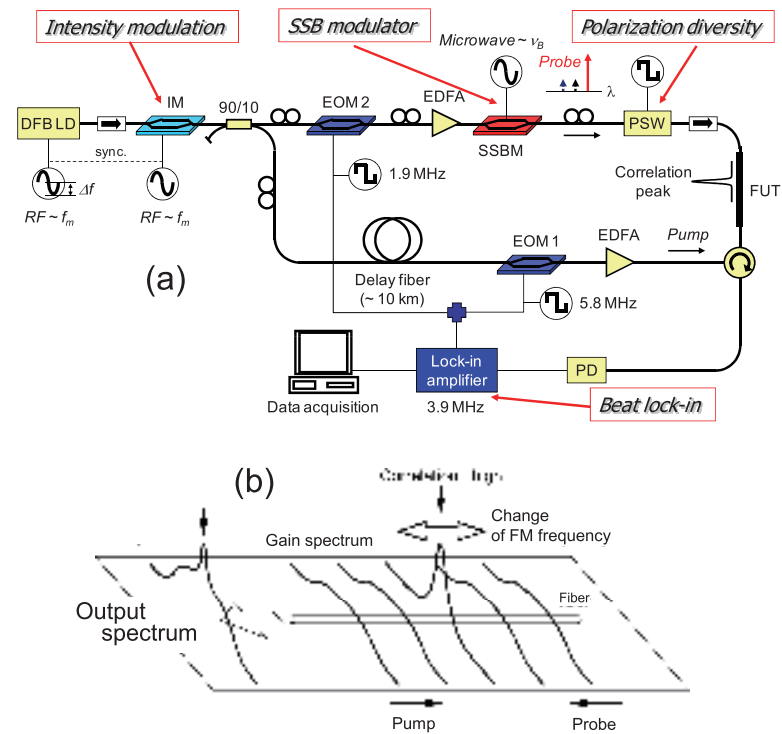

Fig. 3 Brillouin Optical Correlation Domain Analysis. (a) System configuration, and (b) position-selective excitation of the stimulated Brilouin scattering at one point along an optical fiber. ${ }^{32)}$
部分での歪の分布的変化が測定できている ${ }^{34)}$

Fig. 5は，BOCDAのランダムアクセス機能を高速化し た成果である，光ファイバに沿う任意の4点で200サンプ ル/秒で順次BGS形状を測定した。4点でのBFSを同時に 時間関数としてプロットしたのが同図 $(\mathrm{b})$ である ${ }^{41)}$.

BOCDAでの位置選択測定用の光源周波数変調をポン プ部とプローブ部で異なる周波数で行うことによって， 測定位置を光ファイバに沿って自動掃引できる技術も提 案・実証した ${ }^{42)}$. Fig. 6は20トレース/秒で光ファイバに 沿う全分布情報を高速測定した例である ${ }^{42)}$.

この他, 光相関領域リフレクトメトリ (BOCDR法： Brillouin Optical Correlation Domain Reflectometry) \& 提 案・研究している。これは, 光ファイバの片端のみから 光を導入して歪分布センシングを実現する方法であ る ${ }^{43)}$ 。ここでも，光源周波数を正弦波で変調して，ある 特別な位置からのブリルアン散乱のみが測定できる. $10 \mathrm{~mm}$ 空間分解能, $50 \mathrm{~Hz}$ サンプリング速度, $1000 \mathrm{~m}$ 超 の測定レンジが達成されている ${ }^{43-46)}$ ，光源の周波数変調 に同期させて強度変調も併用することで, 不要スペクト

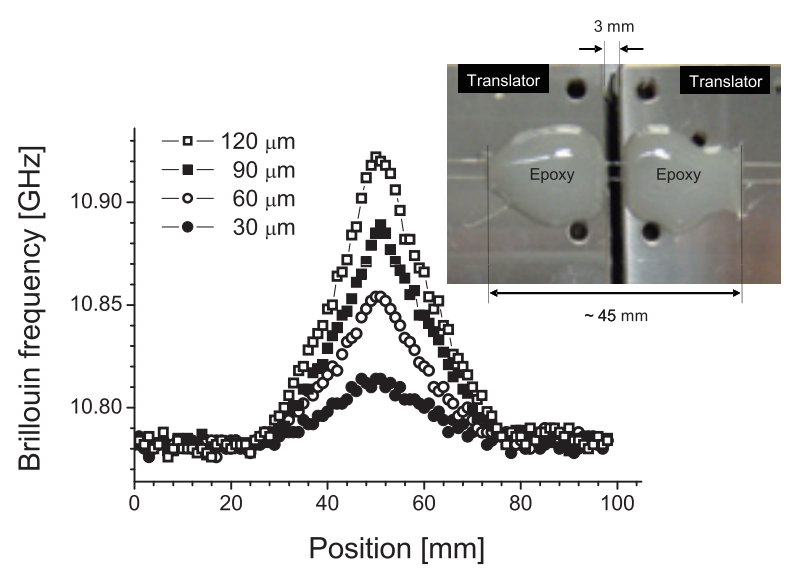

Fig. 4 Demonstration of $1.6 \mathrm{~mm}$ spatial resolution by a BOCDA system. ${ }^{34)}$

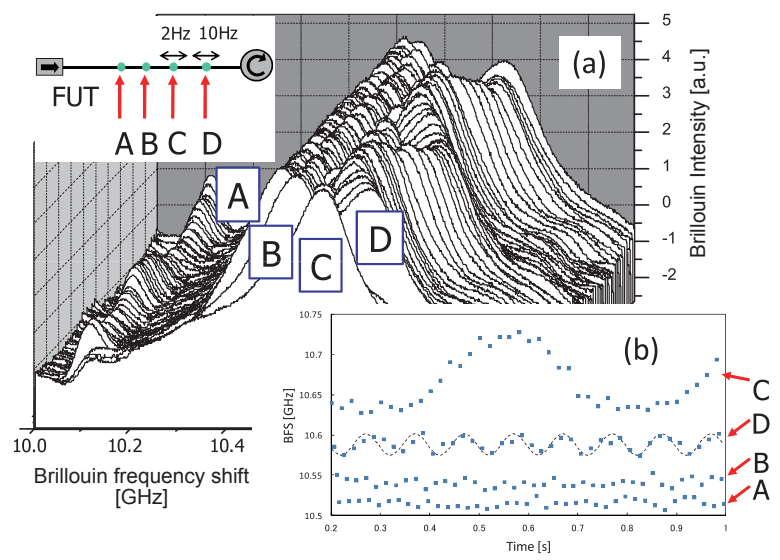

Fig. 5 High speed random accessibility realized by a BOCDA system. Dynamic strain measurement at arbitrary four points along a sensing optical fiber is demonstrated. (a) BGS measurement, and (b) BFS measurement. ${ }^{41)}$ 


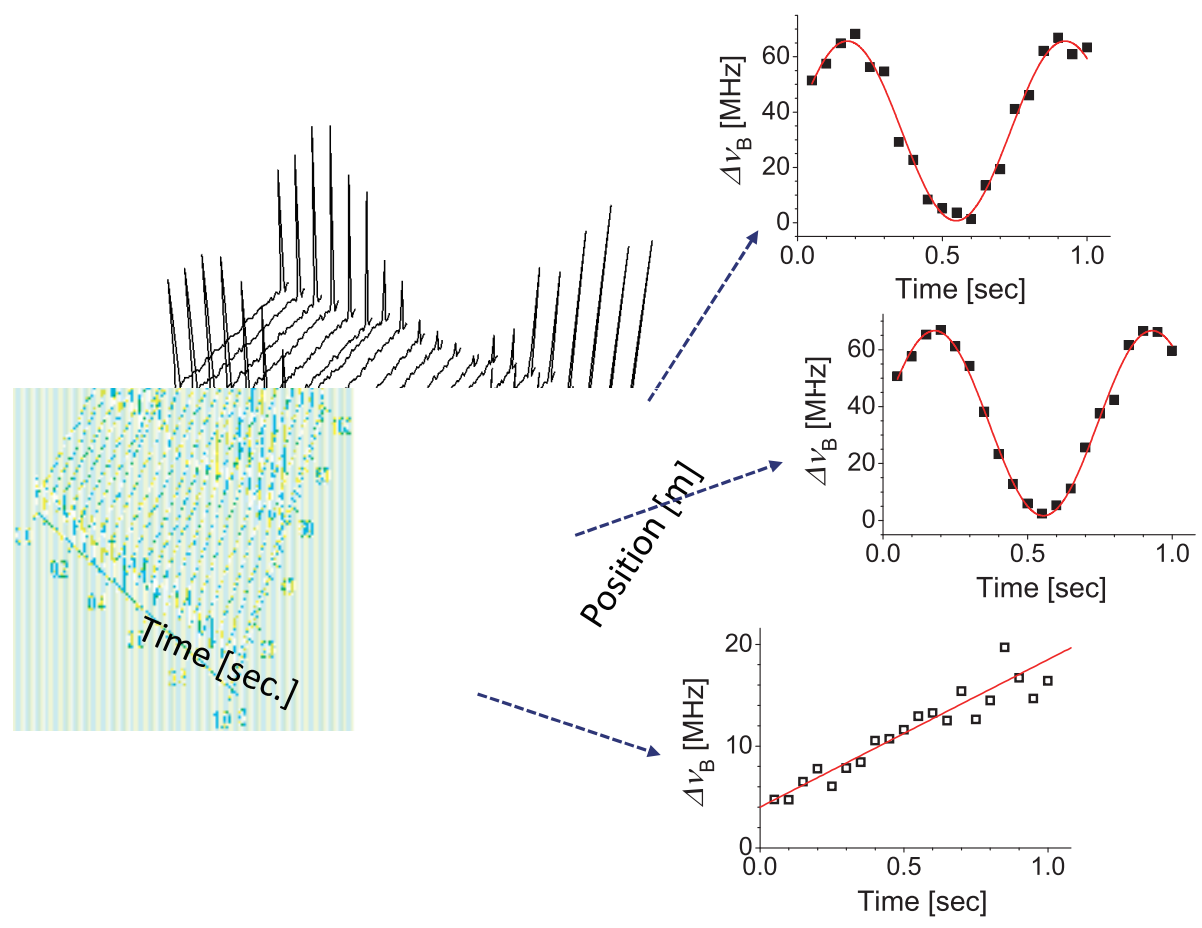

Fig. 6 High speed distributed sensing realized by a BOCDA system. Twenty times of distributed strain measurement is demonstrated within one second. ${ }^{42}$

ル成分を低減することにも成功した ${ }^{46)}$.

4.3 ブリルアンダイナミックグレーティングとその 応用

筆者らは，偏波維持光ファイバのx偏波光で誘導ブリ ルアン散乱を起した際に発生する比較的強い超音波によ り，y偏波光もブラッグ反射されることを実証した ${ }^{47)}$ (Fig. 7参照).このy偏波光の反射波長 (周波数) は偏波維 持光ファイバの複屈折に対応し, $\mathrm{x}$ 偏波光のそれより数 $10 \mathrm{GHz}$ シフトする(Fig. 7 (b) $)^{47)}$. この現象を, Brillouin Dynamic Grating (BDG) と名付けた. BDGに関しては, その基本特性の研究や応用開拓が活発化してい る $^{31,48,49)}$.

BFS とBDGブラッグ反射の周波数シフトの温度と歪依 存性として, Fig. 8の関係が得られた ${ }^{50)}$ 。温度に関して は互いに符号が異なる。これは, 両シフト量の測定から 温度と歪を精度良く測定できることを示している ${ }^{50)}$ 。 BOCDA法により上記の 2 量を分布測定して, 温度と歪の 分布を求める実験系を構成し, 測定レンジを延伸する技

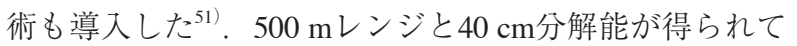
いる. Fig. 9は温度と歪の分離・分布測定結果であ る ${ }^{51)}$. 最近，本測定での空間分解能をさらに向上させる 手法も提案・実証した ${ }^{52)}$.

\section{4 准分布型光ファイバセンシング}

故障が起き易い場所が予見できる場合には, その付近 にのみ短めの分布型センサヘッドを設置するのも意味が ある。このセンサヘッドを多点化したシステムを, 准分 布型と呼ぶ. Fig. 10 (a)は, センサヘッドとして長尺 (a)

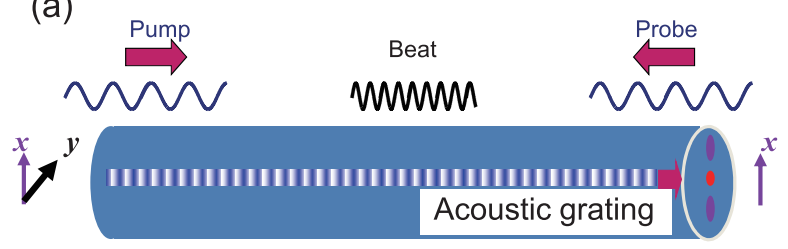

(b)

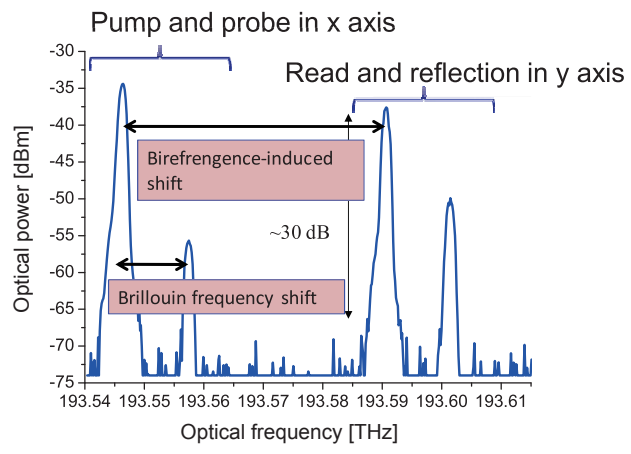

Fig. 7 Dynamic acoustic grating generated with the stimulated Brillouin scattering process in a polarization maintaining fiber. (a) Acoustic grating generation, and (b) Bragg reflection caused for the orthogonal polarization with a frequency difference corresponding to the fiber birefrin gence. ${ }^{41)}$

$(10 \mathrm{~cm})$ の光ファイバグレーティング $(\mathrm{FBG})$ を用いた准 分布型構成システムである ${ }^{53-55)}$ 。同図(b) は，3つの長尺 FBGの内部ブラッグ波長分布を測定した結果で55)，温度 や歪の変化が分布測定されている. 
Strain dependence

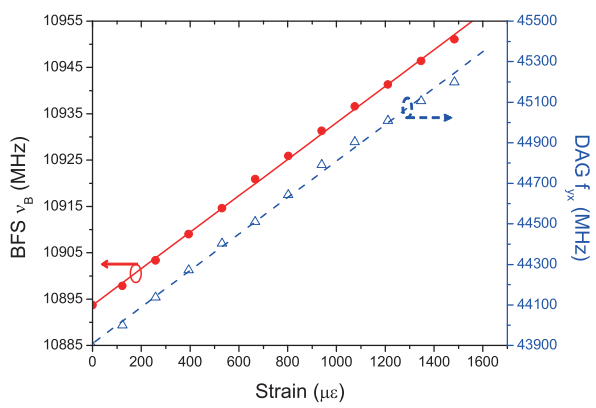

Temperature dependence

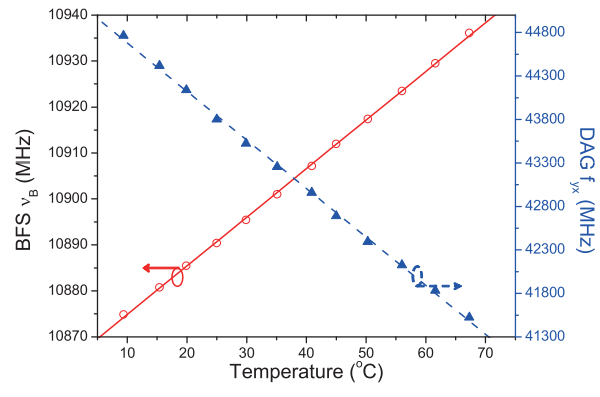

Fig. 8 Strain and temperature dependence of the Brillouin frequency shift and the Bragg reflection frequency shift by the Brillouin dynamic grating. ${ }^{50)}$
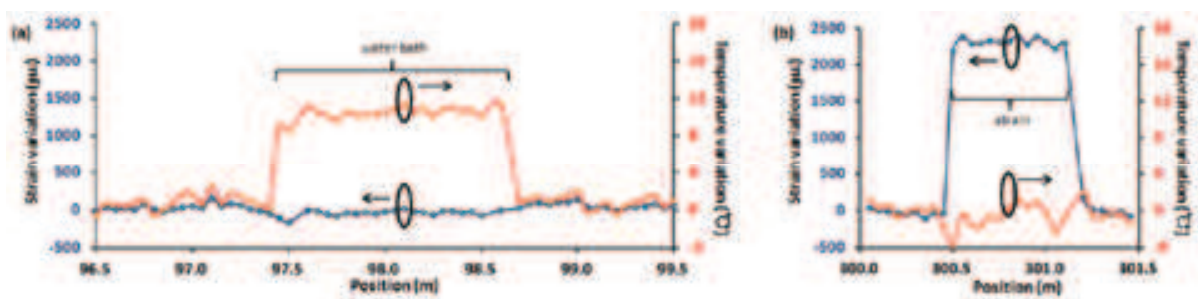

Fig. 9 Discriminative distributed measurement of strain and temperature. ${ }^{51)}$

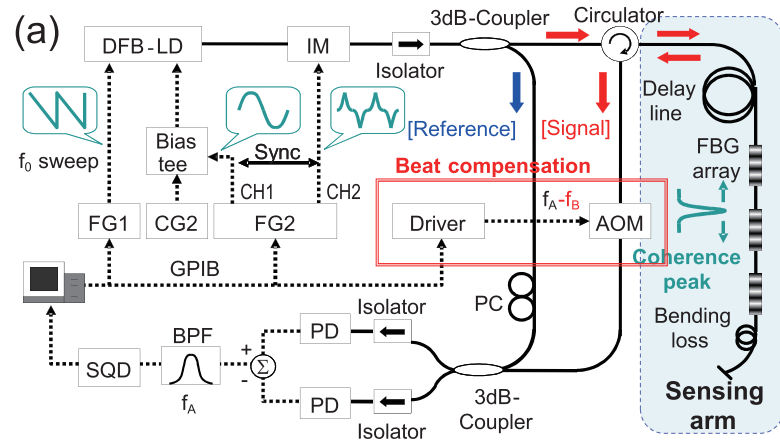

(b)

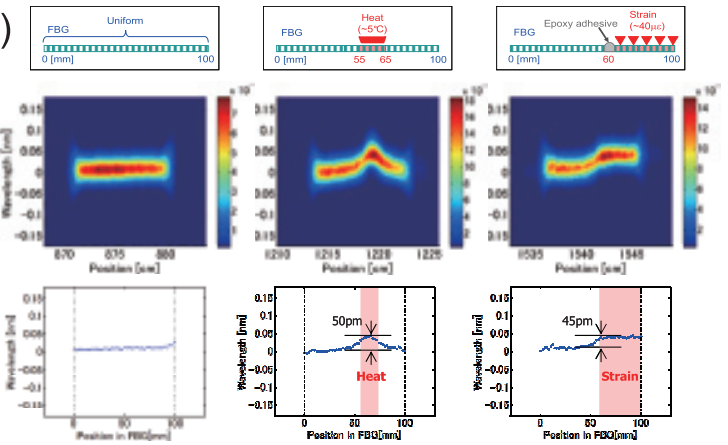

Fig. 10 Quasi-distributed sensing with long-length FBG sensors as short-length distributed sensor heads. (a) System configuration, and (b) distributed sensing with the three long-length FBG sensors. ${ }^{55}$

\section{5. まとめ}

光ファイバセンサ国際会議 $(\mathrm{OFS})$ の歩みを振り返りつ つ, 光ファイバセンシング技術の研究・開発の歴史と現 在を概観した。特に，昨年開催されたOFS22北京会議の
様子を紹介した。 また，本分野の最近のトピックのひと つである「痛みの分かる材料・構造の為の光ファイバ神 経網技術」についても概要を述べ，さらに筆者らが研究 している光相関領域法による技術開発の現状も紹介し た. $\mathrm{mm}$ オーダ空間分解能, $\mathrm{kHz}$ オーダ高速サンプリン グ，ランダムアクセス機能等が実現されている。温度と 歪の高精度 · 同時 ·分布測定法も提案 - 実証されてい 万.

安全・安心, そして持続可能な社会の実現に向けて, 光ファイバセンサ技術は，ユニークなセンシング機能を 提供し続けてゆくものと期待される.

\section{参考文献}

1) 大越 孝敬編：光ファイバセンサ(オーム社, 1986).

2) J. Dakin and B. Culshaw (ed): Optical Fiber Sensors (Artech House Publishers, 1997) Volume I IV.

3) 中村 健太郎：第44回光波センシング技術研究会 (2009) LST44-16, p.107.

4) 田中洋介：第47回光波センシング技術研究会 (2011) LST47-12, p.85.

5) Proc. 22nd International Conference on Optical Fiber Sensors, Beijing, 2012.

6) A. H. Hartog: IEEE/OSA Journal of Lightwave Technology 2 (1984) 76.

7) J. P. Dakin, D. J. Pratt, G. W. Bibby, and J. N. Ross: Electron Lett. 21 (1985) 569.

8) T. Horiguchi and M. Tateda: IEEE/OSA Journal of Lightwave Technology 7 (1989) 1170.

9) K. Hotate and T. Hasegawa: IEICE Trans Electron E83-C (2000) 405.

10) K. Hotate: in Fiber-Optic Gyros (Artech House, 1997) p.167 Optical Fiber Sensors IV, Chap. 11.

11) H. Lefevre: The Fiber-Optic Gyroscope (Artech House, 1993).

12) H. C. Lefèvre, Ph. Martin, T. Gaiffe, Ph. Graindorge, G. Le Boudec, J. Morisse, P. SimonpiOtri, E. Taufflieb, Ph. Vivenot, and 
H. J. Arditty: Fiber Optic and Laser Sensor XII SPIE 2292 (1994) 156.

13) S. Sakai, Y. Fukushima, A. Ohno, and H. Saito: Proc. 18th Intern. Conf. on Optical Fiber Sensors, Cancun, 2006, TuE3.

14）坂井真一郎：計測と制御 51 (2012) 241.

$15)$ S. P. Divakaruni and S. J. Sanders: Proc. 18th Intern. Conf. on Optical Fiber Sensors, Cancun, 2006, MC2.

16) T. Buret, D. Ramecourt, J. Honthaas, E. Willemenot, Y. Paturel, and T. Gaiffe: Proc. 18th Intern. Conf. on Optical Fiber Sensors, Cancun, 2006, MC4, 16.

17）已谷真司, 石島義之, 鈴木秀人, 坂井真一郎, 戸田 知朗, 橋本 樹明, 大野有孝, 臼井竜治, 宮原聖明, 沖倉 晴彦：第51回宇宙科学技術連合講演会 (2007) 3G02.

18) P. Russell: Science 299 (2003) 358.

19) M. J. F. Digonnet, S. W. Lloyd and S. Fan: Proc. 20th International Conference on Optical Fiber Sensors, 2009, 750302.

20) S. W. Lloyd, V. Dangui, M. J. F. Digonnet, S. Fan, and G. S. Kino: Opt. Lett. 35 (2010) 121.

21) V. Dangui, M. J. F. Digonnet, and G. S. Kino: OSA Optics Letters 34 (2009) 875.

22) M. D. Shupe: Appl. Opt. 19 (1980) 654.

23) K. Hotate and G. Hayashi: Proc. 13th Intern. Conf. on Optical Fiber Sensors, 1999, Tu-4-1, p.104.

24) G. A. Sanders, L. K. Strandjord, and T. Q. Qiu: Proc. 18th Intern. Conf. on Optical Fiber Sensors, Cancun, 2006, ME6.

25) X. Wang, Z. He, and K. Hotate: Opt. Express 18 (2010) 1677.

26) X. Wang, Z. He, and K. Hotate: J. Lightwave Technol. 31 (2013) 366.

27）足立 正二, 小山田弥平：計測と制御 51 (2009) 217

28) C.-H. Li et. al.: IEICE Technical Report (2008) OFT 2008-13.

29) S. M. Foaleng, M. Tur, J. C. Beugnot, and L. Thévenaz: IEEE/ OSA Journal of Lightwave Technology 28 (2010) 2993.

30) A. W. Brown, B. G. Colpitts, and K. Brown: J. Lightwave Technol. 25 (2007) 381.

31) K.-Y. Song, S. Chin, N. Primerov, and L. Thévenaz: J. Lightwave Technol. 28 (2010) 2062.

32) K. Hotate, K. Abe, and K.-Y. Song: Photon. Technol. Lett. 18 (2006) 2653.

33) K. Hotate, H. Arai, and K.-Y. Song: SICE J. Control, Meas. and System Integration 1 (2008) 271.

34) K.-Y. Song, Z. He, and K. Hotate: Opt. Lett. 31 (2006) 2526.
35) K.-Y. Song and K. Hotate: Photon. Technol. Lett. 19 (2007) 1928.

36) K. Hotate and Z. He: J. Lightwave Technol. 24 (2006) 2541.

37) S. S. L. Ong, H. Kumagai, H. Iwaki and K. Hotate: Proc. 16th Intern. Conf. on Optical Fiber Sensors, Nara, 2003, We3-3.

38) S. S. L. Ong, M. Imai, Y. Sako, Y. Miyamoto, S. Miura, and K. Hotate: Proc. 16th Intern. Conf. on Optical Fiber Sensors, Nara, 2003, We3-2.

39) T. Yari, K. Nagai, M. Ishioka, K.Hotate, and Y. Koshioka: Proc. 15th Annual Intern. Symp. on Smart Structures and Materials \& Nondestructive Evaluation and Health Monitoring, San Diego, 2008, 6933-29.

40) 水口周, 中村達也, 灘部岳晃, 西川雅章, 武田展雄, 岸眞人, 保立和夫：日本航空宇宙学会論文集 59 (2011) 176.

41) K. Hotate, M. Numasawa, M. Kishi, and Z. He: 3rd Asia Pacific Optical Sensors Conf. (APOS 2012), Sydney, Australia, 2012, APO12-99, WB-3.

42) K.-Y. Song, M. Kishi, Z. He, and K. Hotate: Opt. Lett. 36 (2011) 2062.

43) Y. Mizuno, Z. He, and K. Hotate: Photon. Technol. Lett. 21 (2009) 474.

44) Y. Mizuno, W. Zou, Z. He, and K. Hotate: J. Lightwave Technol. 28 (2010) 3300.

45) Y. Mizuno, Z. He, and K. Hotate: OSA Opt. Express 18 (2010) 5926.

46) S. Manotham, M. kishi, Z. He, and K. Hotate: 3rd Asia Pacific Optical Sensors Conf. (APOS 2012), Sydney, Australia, 2012, APO12-51, Th-C23.

47) K.-Y. Song, W. Zou, Z. He, and K. Hotate: Opt. Lett. 33 (2008) 926.

48) Y. Dong, L. Chen, and X. Bao: Opt. Lett. 35 (2010) 193.

49) K.-Y. Song and H.-J. Yoon: Opt. Lett. 35 (2010) 2958.

50) W. Zou, Z. He, and K. Hotate: Opt. Express 17 (2009) 1248.

51) R. K. Yamashita, W. Zou, Z. He, and K. Hotate: Photon. Technol. Lett. 24 (2012) 1006.

52) R. K. Yamashita, Z. He, and K. Hotate: Proc. 22nd International Conference on Optical Fiber Sensors, Beijing, 2012, PO3-32.

53) K. Hotate and K. Kajiwara: Opt. Express 16 (2008) 7881.

54) K. Kajiwara and K. Hotate: Appl. Phys. Express 2 (2009) 082401.

55) K. Kajiwara and K. Hotate: Photon. Technol. Lett. 23 (2011) 1555 . 